\title{
Detection of Chlorothalonil in Dew Water Following Aerial Spray Application and Its Role in the Control of Black Sigatoka in Banana
}

\author{
J. R. Washington, J. Cruz, and M. Fajardo, ISK Biosciences Corporation, La Lima, Honduras
}

\begin{abstract}
Washington, J. R., Cruz, J., and Fajardo, M. 1998. Detection of chlorothalonil in dew water following aerial spray application and its role in the control of black Sigatoka in banana. Plant Dis. 82:1191-1198.

A standardized bioassay measuring the growth inhibition of Aspergillus niger in vitro allowed the detection of small concentrations $(0.1$ to $20 \mu \mathrm{g} / \mathrm{ml})$ of chlorothalonil present in dew water on both the adaxial and abaxial surface of banana leaves in a commercial plantation receiving aerial sprays. Chlorothalonil concentrations detected in dew water on the banana leaf surface were within the range of concentrations required to prevent Mycosphaerella fijiensis (causal agent of black Sigatoka) ascospore germination in laboratory bioassays. When 9-cm-diameter banana leaf disks inoculated with $M$. fijiensis ascospores were immersed for $4 \mathrm{~h}$ in water containing 0.1 to $0.6 \mu \mathrm{g}$ of chlorothalonil per $\mathrm{ml}$, ascospore germination was inhibited by $96.9 \%$. The $\mathrm{EC}_{50}$ values for inhibition of ascospore germination were between 0.01 and $0.03 \mu \mathrm{g} / \mathrm{ml}$ for chlorothalonil and between 3.2 and $3.7 \mu \mathrm{g} / \mathrm{ml}$ for mancozeb. Following a 4-h exposure to chlorothalonil and mancozeb, and subsequent removal of the fungicides by a washing step, ascospores failed to germinate, indicating that both fungicides are fungicidal to $M$. fijiensis, not fungistatic. Recovery analysis of chlorothalonil spray droplet deposits and active ingredient on deposition cards in the field during aerial spray applications indicated that detectable fungicide deposition on the abaxial leaf surface occurs only when the banana leaf-target is vertical or nearly so. The significance of this observation in relation to the control of black Sigatoka with protectant fungicides is discussed.
\end{abstract}

The protectant fungicides chlorothalonil and mancozeb commonly are applied to control black Sigatoka (Mycosphaerella fijiensis Morelet) in banana (Musa AAA). These fungicides usually are applied by aircraft at low volumes ( 15 to 25 liters $^{-1} \mathrm{~h}^{-1}$ ). Most of the fungicide is deposited on the adaxial surface of horizontal leaves. Fungicide deposits are visible on the abaxial surface of newly emerged, vertical leaves, but these deposits often are sporadically and sparsely distributed. Much of the abaxial leaf surface apparently is unprotected from infection initiated by airborne ascospore inocula of M. fijiensis. Ascospores are considered the most important inoculum source of $M$. fijiensis (11). Stover (10) suggested that the abaxial surface of young leaves is the most important infection site for the aerially borne ascospores of $M$. fijiensis, although ascospore inoculum has been found to be evenly distributed throughout the banana leaf canopy (16). Washington et al. (17) reported that the primary infection site of $M$. fijiensis is the abaxial leaf surface. The small amount of visible fungicide residue deposited on

Corresponding author: J. R. Washington, 6964 NW 55th St., Suite DFFI, Miami, FL 33166-5632.

Accepted for publication 3 August 1998.

Publication no. D-1998-0901-02R

(C) 1998 The American Phytopathological Society the abaxial leaf surface appears inconsistent with the successful disease control obtained with the protectant fungicides chlorothalonil and mancozeb.

Washington (15) reported that the likely medium of fungicide uptake by $M$. fijiensis ascospores on the banana leaf surface was free water containing dissolved chlorothalonil and mancozeb. This conclusion suggests that water present on the leaf surface and formed nightly by dew in the tropics (8), as well as water from rainfall, could play a significant role in disease control by redistributing fungicide over the leaf surface and serving as the bridge between spore and fungicide. Confirming that protectant fungicides are redistributed from sparse deposits on the abaxial leaf surface may help explain how these fungicides control black Sigatoka and may indicate spray application strategies for enhanced disease control.

The objectives of this study were to (i) assess the utility of a bioassay for estimating chlorothalonil concentrations in dew water, (ii) examine the deposition patterns of aerial spray applications of chlorothalonil on banana foliage, (iii) investigate the relationship between aerial spray deposition patterns on banana foliage and chlorothalonil concentration in dew water present on the leaf surface, (iv) determine if chlorothalonil concentrations detected in the dew water were adequate to inhibit $M$. fijiensis ascospore germination, (v) compare toxicities of chlorothalonil and man- cozeb to ascospores of M. fijiensis, and (vi) determine if chlorothalonil and mancozeb are fungicidal or fungistatic toward $M$. fijiensis ascospores.

\section{MATERIALS AND METHODS}

Laboratory studies. The effect of chlorothalonil and mancozeb on M. fijiensis ascospore germination was studied in vitro on (i) fungicide-amended $2 \%$ water agar, (ii) ascospore-inoculated leaves immersed in fungicide suspension, and (iii) ascospore-inoculated leaves sprayed with dilute fungicide suspension (chlorothalonil only). Commercial formulations of chlorothalonil (Bravo 720; Zeneca) and mancozeb (Dithane MB; Rohm and Haas) were diluted to concentrations of 0.01 to $0.6 \mu \mathrm{g}$ a.i./ml and 0.5 to $7.0 \mu \mathrm{g}$ a.i. $/ \mathrm{ml}$, respectively.

In experiments exposing ascospores to fungicide suspensions, ascospores first were discharged onto the abaxial surface of 9-cm-diameter banana leaf disks, as described by Washington (15), and placed in fungicide suspensions for $4 \mathrm{~h}$ in glass petri dishes with the abaxial leaf surface facing down. A 250-ml glass beaker was placed on top of each leaf disk to ensure that it was completely submerged in the fungicide suspension. Leaf disks were then removed from the fungicide suspensions and rinsed three times with sterile distilled water, placed abaxial side up in petri dishes containing a moist paper towel, misted with sterile distilled water to promote germination, and incubated on the benchtop for 48 $\mathrm{h}$ at room temperature $\left(25\right.$ to $\left.28^{\circ} \mathrm{C}\right)$. The treatment sprayed with a dilute suspension of chlorothalonil was prepared by following the inoculation procedures described above, but instead of immersing leaf disks in fungicide suspensions in petri dishes, a $\mathrm{CO}_{2}$-pressurized Chromist sprayer (Fisher Scientific, Atlanta, GA) was used to make a single application of sterile distilled water containing $0.6 \mu \mathrm{g}$ of chlorothalonil per $\mathrm{ml}$ and $0.1 \%$ Tween 20 onto the leaf disks following inoculation with ascospores. Control leaf disks were immersed in sterile distilled water containing no fungicide. Spores were stained with a $1 \%$ Rose Bengal (Fisher Scientific), as described by Washington (15). Three hundred spores per leaf disk were observed microscopically $(\times 100)$ to determine percent germination. Spores with germ tubes longer than onehalf the length of the spore were considered germinated. Percent germination was averaged for all four replications (leaf 
disks) per treatment. All experiments were conducted three times. Where error variances were homogenous according to Bartlett's test, data were combined across experiments.

Fungicides in amended water agar were compared by adding diluted concentrations of fungicide to cooled $\left(50^{\circ} \mathrm{C}\right)$ agar before pouring them into $9-\mathrm{cm}$ petri dishes. $M$. fijiensis ascospores were discharged onto the solidified agar and incubated for $48 \mathrm{~h}$ on the benchtop at room temperature, and three hundred spores per petri dish were observed microscopically $(\times 100)$ without staining. Dishes of unamended water agar served as controls. There were four replications per treatment. The experiments were conducted three times. Data were analyzed by analysis of variance using SAS ver. 6.04 statistical software (SAS Institute, Cary, NC). Error variances from the three experiments were homogenous according to Bartlett's test, so data were combined. $\mathrm{EC}_{50}$ and $\mathrm{EC}_{90}$ values, representing reduction of ascospore germination by 50 and $90 \%$, were determined by regressing probit-transformed percent inhibition of ascospore germination against $\log _{10}$ concentrations of the fungicides.

Bioassay method for estimating chlorothalonil concentration. A bioassay was developed to relate the percent growth inhibition of Aspergillus niger in vitro with the chlorothalonil concentration $(\mu \mathrm{g} / \mathrm{ml})$ present in dew water. Sterile filter paper disks (Fisherbrand P5 filter paper, Fisher Scientific) $2 \mathrm{~cm}$ in diameter, were saturated with leaf surface moisture present on banana leaves in the field by lightly pressing the disks against the leaf with forceps for 3 to $5 \mathrm{~s}$. These disks were then placed on a nutrient medium (potato dextrose agar [PDA], Fisher Scientific) in petri dishes. The medium contained penicillin at 150 $\mu \mathrm{g} / \mathrm{ml}$ and streptomycin sulfate at $50 \mu \mathrm{g} / \mathrm{ml}$ to inhibit growth of bacterial contaminants. Conidia of $A$. niger $\left(1 \times 10^{4} \mathrm{CFU} \mathrm{ml}{ }^{-1}\right)$ were added to the medium just prior to pouring it into $9-\mathrm{cm}$ petri dishes (PDAAspergillus dishes). Four filter paper disks (subsamples) were placed on each dish, and after incubation for $72 \mathrm{~h}$ on the benchtop at room temperature, the percent area covered by $A$. niger was visually estimated on each disk. These data were converted to percent inhibition of $A$. niger growth using the equation $[100-Y]$, where $Y=$ percent area covered by $A$. niger growth. Controls consisted of PDA-Aspergillus dishes with filter paper disks saturated with sterile distilled water. The control disks were always completely covered with $A$. niger growth after $72 \mathrm{~h}$.

The A. niger isolate used was obtained from a lime peel and was chosen because it was an easily cultured, fast-growing organism whose growth was inhibited by chlorothalonil in vitro. The same isolate was used throughout the studies by maintaining a stock culture on PDA at $4^{\circ} \mathrm{C}$ and subculturing it when necessary. In order to estimate chlorothalonil concentrations in dew water from the field, a standard curve was plotted from data of probit-transformed percent inhibition of A. niger growth against $\log _{10}$ chlorothalonil concentration $(\mu \mathrm{g} / \mathrm{ml})$ in filter paper disks saturated with fungicide suspensions, using known concentrations of chlorothalonil. Each chlorothalonil concentration was replicated four times. The experiment was performed three times. The error variances in the three experiments were tested for homogeneity using Bartlett's test. Since the variances were homogenous, data from the three experiments were combined for simple linear regression analysis, which was performed using SAS ver. 6.04.

Field studies. Chlorothalonil concentrations present in dew water on banana leaves were estimated by sampling the leaf surfaces in two commercial banana plantations. Sampling was conducted in the early morning (5:00 to 8:00 A.M.), when the dew formed during the evening had not yet evaporated. Samples were taken primarily from the abaxial leaf surface of young leaves since this is thought to be the most important site for $M$. fijiensis infection (10). Four subsamples were taken per leaf by pressing the filter paper disks lightly against the banana leaf in the positions shown in Figure 1. The filter paper disks were then immediately placed on PDAAspergillus dishes in the field, and when sampling was completed, the dishes were brought back to the laboratory and left on the lab bench at room temperature for $72 \mathrm{~h}$. Percent growth inhibition of $A$. niger was estimated and averaged among the four subsamples per petri dish. These data were converted to estimates of chlorothalonil concentration $(\mu \mathrm{g} / \mathrm{ml})$ utilizing the regression line plotted for the standards described above.

Dew water sampling was conducted during September and October 1997 in 50 $\times 50 \mathrm{~m}$ plots consisting of nonfruiting banana plants 1 to $2 \mathrm{~m}$ high and located within Banderas and Casmul farms, large plantations located in Ticamaya and San Manuel, Cortés, Honduras, respectively. The two plantations received aerial applications of chlorothalonil (BRAVO 720 [720 $\mathrm{g}$ a.i. liter $\left.^{-1}\right]$ ) every 5 to 7 days at a rate of 1.0 liter ha- in a total spray volume of 20 liters $\mathrm{ha}^{-1}$. Immature plants were selected in order to facilitate sampling. Canopy structure of young plants is similar to that of mature, fruiting plants (12). The emerging leaf (leaf C), the first fully expanded leaf (leaf 1), and the second fully expanded leaf (leaf 2) were sampled (Fig. $2 \mathrm{~A}$ to $\mathrm{C}$ ). Sampling was always conducted $24 \mathrm{~h}$ after a spray application.

In addition to the $A$. niger growth inhibition assay, dew water samples were collected directly from the surface of five leaves with a micropipette, placed in 1.5$\mathrm{ml}$ plastic microfuge tubes, preserved with 1 drop of $10 \mathrm{~N} \mathrm{H}_{2} \mathrm{SO}_{4}$, and sent to Ricerca Inc. (Painesville, Ohio) for quantitative analysis of chlorothalonil. Sampling in this manner was conducted once $24 \mathrm{~h}$ after a spray application in Casmul Farm.

Fungicide droplet recovery patterns in relation to leaf angle and surface were assessed by placing collection devices, which simulated the architecture of banana plants, under the spray swath of a Grum-
Fig. 1. Diagrammatic representation of sampling positions of subsamples 1 to 4 utilized to sample for chlorothalonil concentration in dew water on banana leaves in the field. Filter paper disks were pressed lightly against the leaf surface at the positions shown until saturated with dew water and then immediately placed on PDA-Aspergillus dishes. 
man Ag Cat piston engine airplane during application of chlorothalonil (BRAVO 720 [1 liter ha ${ }^{-1}$ ]) in Casmul Farm. The airplane was fitted with 10 Micronair AU5000 rotary atomizers (Micronair Corporation, Miami, FL) covering a spray swath width of $24 \mathrm{~m}$ and was calibrated to deliver a total spray volume of 20 liters $\mathrm{ha}^{-1}$. The collection devices (Fig. 3) were designed with a tripod base fitted with a 75$\mathrm{cm}$-tall central pole. Attached to the central pole in a radial fashion were $1-\mathrm{cm}-$ diameter, 25-cm-long wooden dowels with a $26 \times 18 \times 0.5 \mathrm{~cm}$ thick piece of plywood attached at the end. The wooden dowels were attached to the central pole at specific angles, which represent the range of leaf angles found in banana plants. A 15-cm-tall, 2-cm-diameter vertical dowel was placed on top of the central pole to represent a 3-day-old emerging leaf (leaf C) of a banana plant. Immediately below this dowel was a rectangular $(26 \times 18 \times 0.5 \mathrm{~cm}$ thick $)$ board representing the youngest fully opened leaf (leaf 1). Leaves 2, 3, 4, and 5 were represented by board angles with respect to the vertical dowel of $5^{\circ}, 30^{\circ}, 45^{\circ}$, and $90^{\circ}$, respectively. Two $52 \times 76 \mathrm{~mm}$ water-sensitive spray cards (Spraying Systems, Wheaton, IL) were attached to both the upper and lower surface of the plywood boards representing leaves 1 to 5 , and wrapped around the top dowel representing leaf $\mathrm{C}$. The collection devices with attached spray cards were then placed in an open area within Casmul Farm during a spray application. Immediately after application, the spray cards were removed, labeled, and stored in a sealed plastic bag until assessment.

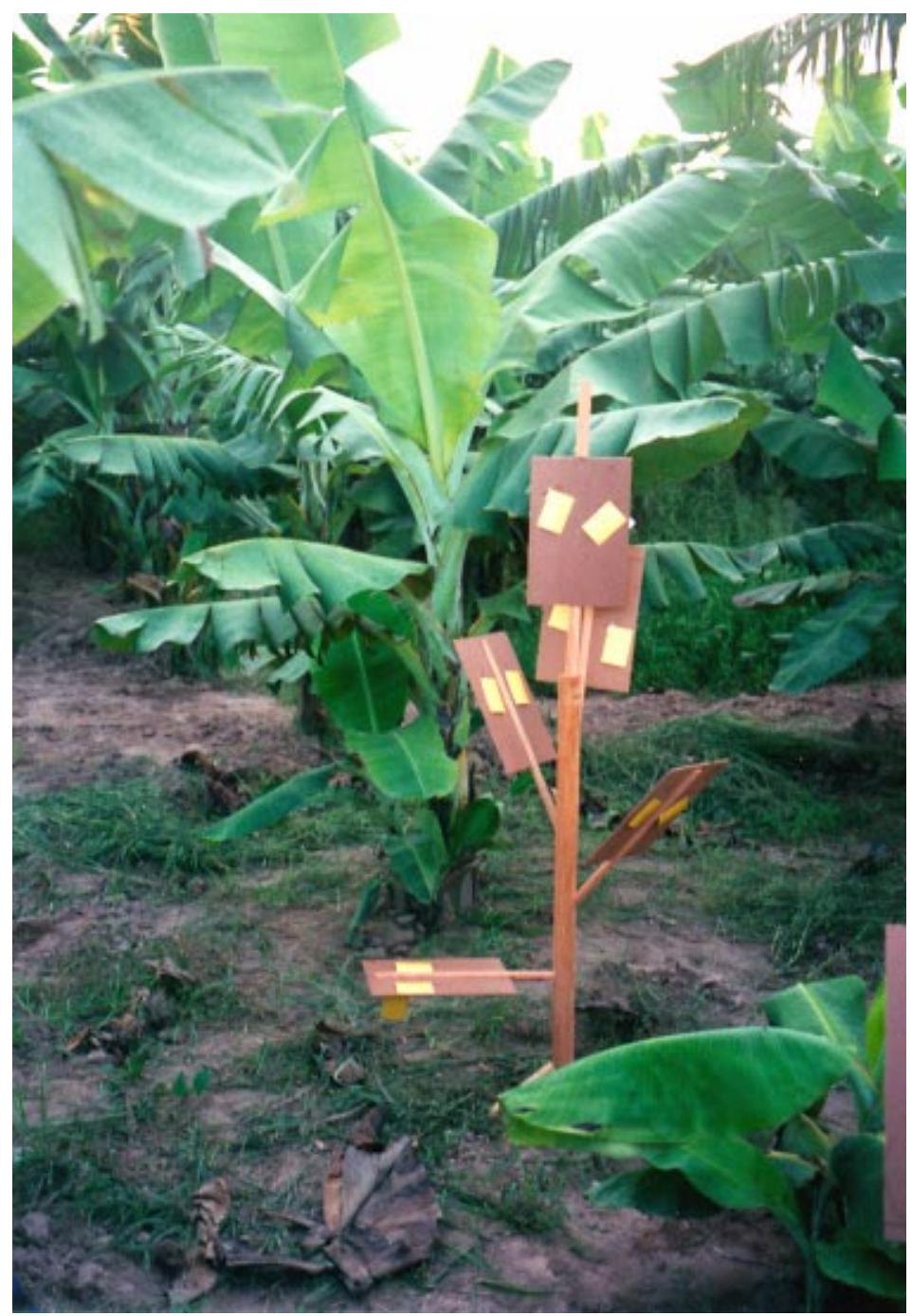

Fig. 3. Collection device used to sample deposition of fungicide spray droplet deposits on watersensitive paper during aerial applications.
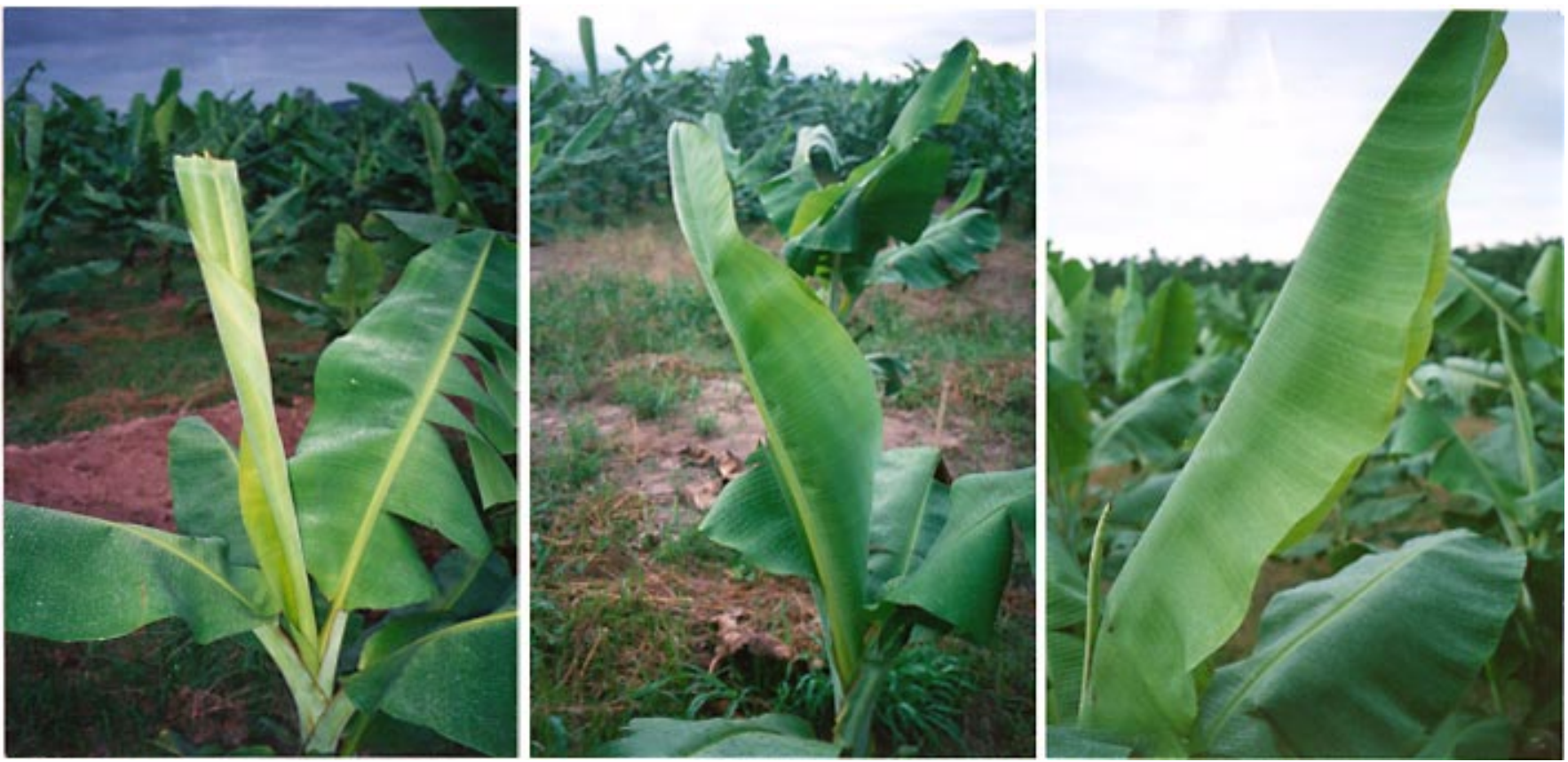

Fig. 2. Photographs of leaf stages utilized for dew water sampling with filter paper disks in the Aspergillus niger growth inhibition bioassay, showing (A) a 3- to 4-day-old emerging leaf, (B) an 8- to 10-day-old emerging leaf, and (C) a fully opened leaf 1 next to a 1-day-old emerging leaf. 
The number of spray droplet deposits per $\mathrm{cm}^{2}$ was quantified under a stereomicroscope at $\times 20$ magnification. Spray droplet deposits were counted in four different, arbitrarily selected, $1 \mathrm{~cm}^{2}$ areas within each spray card. The experiment was conducted twice (two separate dates) using a total of eight replications (sampling devices) per experiment. Spray droplet deposit density data were analyzed by an analysis of variance (SAS ver. 6.04).

Fungicide droplet deposit recovery following an aerial application was assessed in the upper canopy of banana plants in Banderas Farm. FD\&C Red no. 40 powdered dye (Warner Jenkinson Co., St. Louis. $\mathrm{MO})$ was added to the spray mix (10 $\mathrm{g} \mathrm{liter}^{-}$ $\left.{ }^{1}\right)$ with chlorothalonil [BRAVO $720(75 \mathrm{ml}$ liter $\left.{ }^{-1}\right)$ ] to facilitate detection of spray droplet deposits on $15 \times 15 \mathrm{~cm}$ white, double glossy Kromekote paper (Champion International Corp., Stamford, CT). Water-sensitive paper was not utilized because surface moisture from the banana leaves stained the cards. Eighteen banana plants were sampled. The plants were divided into two lines of nine plants each, with each line separated by $10 \mathrm{~m}$. Spray cards were placed in each plant on the emerging leaf $\mathrm{C}$ and the three youngest fully opened leaves (leaves 1 to 3 ) in the following manner: On leaf $\mathrm{C}$, one spray card was placed approximately midway up the height of the leaf. On each of leaves 1 to 3 , three spray cards were placed on both the upper and lower surfaces, with one spray card at the base, one in the center of the leaf adjacent to the midvein, and one at the apex of the leaf. Droplet deposits were counted manually by observation under a stereomicroscope $(\times 20)$. Orthogonal contrast comparisons of droplet deposit data failed to detect significant $(P<0.05)$ differences among sampling positions on the same leaf surface, so data were combined for each surface on each leaf.

Recovery of chlorothalonil on banana leaves during an aerial application also was assessed by placing $5 \times 5 \mathrm{~cm}$ Fisherbrand P5 filter paper squares on leaves in the same positions as used for recovery of spray droplets described above except that leaf 3 was not sampled. The filter paper squares were placed on top of $8 \times 8 \mathrm{~cm}$ aluminum foil squares to prevent contamination of the filter paper with chlorothalonil present on the banana leaves from previous applications. Immediately after application, the filter paper squares were placed in $20 \mathrm{ml}$ glass scintillation vials, packaged, and sent to Ricerca, Inc. for chlorothalonil analysis. The experiment was a completely randomized design with nine replications (plants). The study was conducted only once due to the high cost of analysis. Data were analyzed by an analysis of variance (SAS ver. 6.04).

\section{RESULTS}

Laboratory studies. $M$. fijiensis ascospores on banana leaf disks exposed to
Table 1. Inhibition of Mycosphaerella fijiensis ascospore germination on banana leaf disks by chlorothalonil suspensions ${ }^{\mathrm{y}}$

\begin{tabular}{llccc}
\hline & & \multicolumn{3}{c}{ Ascospore germination (\%) } \\
\cline { 3 - 5 } Treatment & Exposure method & Experiment 1 & Experiment 2 & Experiment 3 \\
\hline $\begin{array}{c}\text { Chlorothalonil } \\
(0.6 \mu \mathrm{g} / \mathrm{ml})\end{array}$ & Immersion in water $-4 \mathrm{~h}$ & $0.9 \mathrm{c}$ & $4.8 \mathrm{c}$ & $1.6 \mathrm{c}$ \\
$\begin{array}{c}\text { Chlorothalonil } \\
(0.6 \mu \mathrm{g} / \mathrm{ml})\end{array}$ & Sprayed on leaf disks & $10.9 \mathrm{~b}$ & $20.5 \mathrm{~b}$ & $14.8 \mathrm{~b}$ \\
Control & None & $99.8 \mathrm{a}$ & $99.9 \mathrm{a}$ & $99.2 \mathrm{a}$ \\
\hline
\end{tabular}

y Ascospore-inoculated leaf disks either were immersed in a chlorothalonil suspension for $4 \mathrm{~h}$ or the chlorothalonil suspension was sprayed onto the leaf disks.

${ }^{\mathrm{z}}$ Means followed by the same letter in each column are not significantly different according to Duncan's multiple range test $(P>0.05)$.

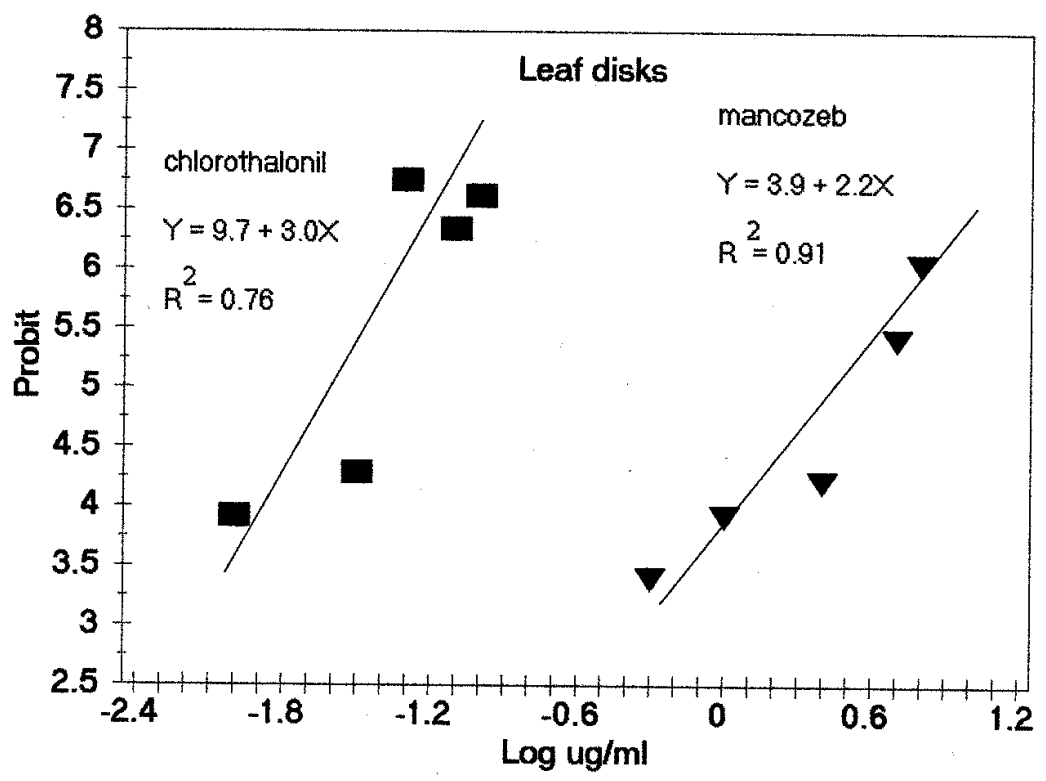

Fig. 4. Linear regression line of probit-transformed percent inhibition of Mycosphaerella fijiensis ascospore germination on banana leaf disks submerged for $4 \mathrm{~h}$ in chlorothalonil and mancozeb suspensions.

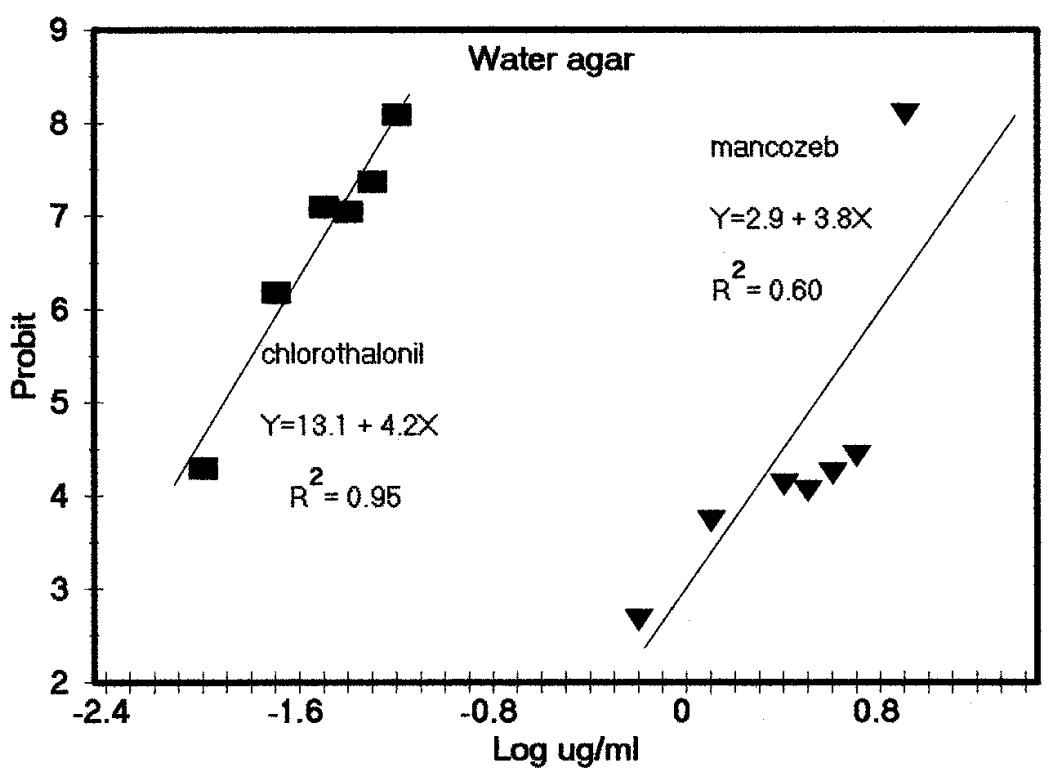

Fig. 5. Linear regression of probit-transformed percent inhibition of Mycosphaerella fijiensis ascospore germination on water agar amended with chlorothalonil and mancozeb. 
chlorothalonil at $0.6 \mu \mathrm{g} / \mathrm{ml}$ either by immersion in a fungicide suspension for $4 \mathrm{~h}$ or by spraying the fungicide suspension onto leaf disks showed a reduction in germination compared with the control (Table 1). Ascospore germination was lowest on leaf disks immersed in the chlorothalonil suspension. Ascospores on leaf disks sprayed with a $0.6 \mu \mathrm{g} / \mathrm{ml}$ chlorothalonil suspension showed a significantly higher percent germination compared with the immersion method, but germination was

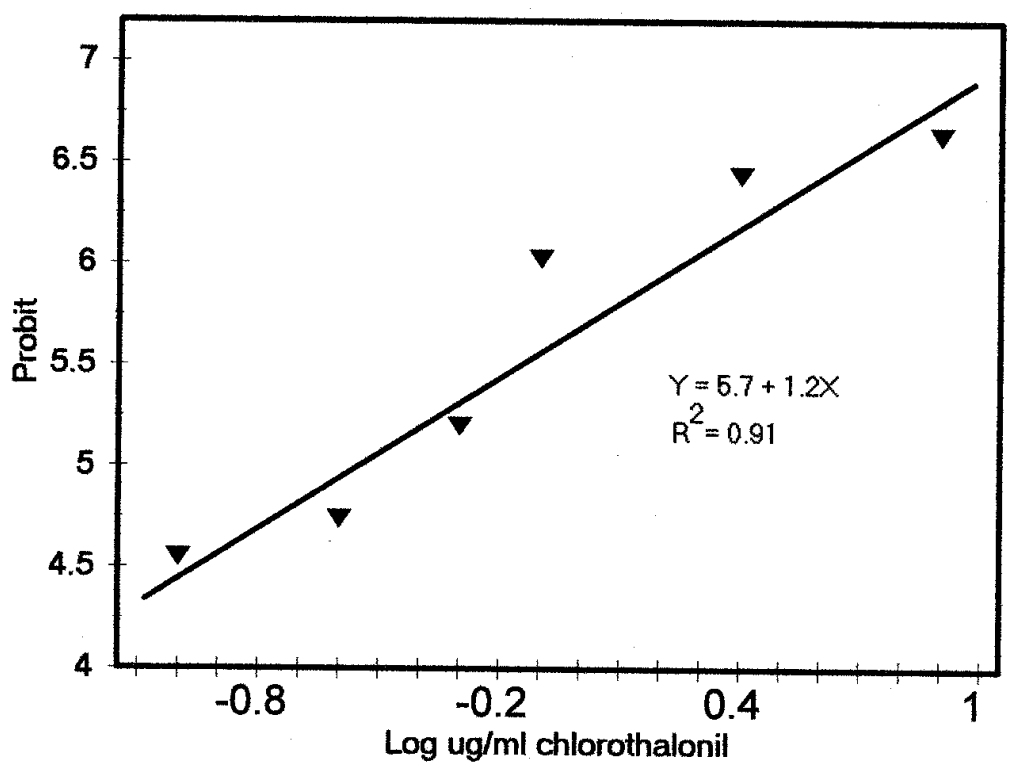

Fig. 6. Linear regression line of probit-transformed percent growth inhibition of Aspergillus niger on filter paper disks versus $\log _{10} \mu \mathrm{g} / \mathrm{ml}$ chlorothalonil.

Table 2. Percent growth inhibition of Aspergillus niger on filter paper disks saturated with dew water from banana leaves and corresponding estimates of chlorothalonil concentration $(\mu \mathrm{g} / \mathrm{ml})$ present in samples from Banderas Farm $24 \mathrm{~h}$ after an aerial spray application of chlorothalonil

\begin{tabular}{lccccc}
\hline Location & $\begin{array}{c}\text { Mean growth } \\
\text { inhibition } \\
(\boldsymbol{\%})^{\mathbf{y}}\end{array}$ & $\begin{array}{c}\text { Mean } \\
\text { chlorothalonil } \\
\text { conc. }(\boldsymbol{\mu g} / \mathbf{m l})^{\mathbf{z}}\end{array}$ & $\begin{array}{c}\text { Range of } \\
\text { chlorothalonil } \\
\text { conc. }(\boldsymbol{\mu g} / \mathbf{m l})\end{array}$ & $\begin{array}{c}\text { Total } \\
\text { samples }\end{array}$ & $\begin{array}{c}\text { Samples with } \\
\text { chlorothalonil } \\
\text { conc. } \geq \mathbf{0 . 1} \boldsymbol{\mu g} / \mathbf{m l}\end{array}$ \\
\hline $\begin{array}{c}\text { Adaxial } \\
\text { surface, leaf } 1\end{array}$ & $84.3 \mathrm{a}$ & $7.9 \mathrm{a}$ & 0.1 to $>20$ & 19 & 19 \\
$\begin{array}{c}\text { Abaxial } \\
\text { surface, leaf } 1\end{array}$ & $74.2 \mathrm{a}$ & $6.1 \mathrm{a}$ & 0.0 to $>20$ & 16 & 15 \\
$\begin{array}{c}\text { Abaxial } \\
\text { surface, leaf C }\end{array}$ & $58.2 \mathrm{~b}$ & $1.4 \mathrm{~b}$ & 0.0 to 9.6 & 17 & 16 \\
\hline
\end{tabular}

${ }^{y}$ Means followed by the same letter in each column are not statistically different according to Duncan's multiple range test $(P>0.05)$.

${ }^{\mathrm{z}}$ Estimate is calculated from regression equation plotting probit-transformed percent growth inhibition of $A$. niger against $\log _{10} \mu \mathrm{g} / \mathrm{ml}$ chlorothalonil (Fig. 6).

still low (15.4\%) compared with the control.

Ascospores on banana leaf disks showed significantly $(P<0.05)$ reduced germination compared with the control when exposed to chlorothalonil and mancozeb in fungicide suspensions for $4 \mathrm{~h}$ at a concentration as low as $0.01 \mu \mathrm{g} / \mathrm{ml}$ for chlorothalonil and $1.0 \mu \mathrm{g} / \mathrm{ml}$ for mancozeb. At a chlorothalonil concentration of $0.05 \mu \mathrm{g} / \mathrm{ml}$, ascospore germination dropped to $4.0 \%$. For mancozeb, $7.0 \mu \mathrm{g} / \mathrm{ml}$ was necessary before a similar level of inhibition was observed. Linear regression of probit-transformed percent inhibition of ascospore germination versus $\log _{10} \mu \mathrm{g} / \mathrm{ml}$ fungicide in water (Fig. 4) resulted in estimates for $\mathrm{EC}_{50}$ and $\mathrm{EC}_{90}$ values for chlorothalonil of 0.03 and $0.06 \mu \mathrm{g} / \mathrm{ml}$. The $\mathrm{EC}_{50}$ and $\mathrm{EC}_{90}$ values for mancozeb were estimated to be 3.2 and $12.0 \mu \mathrm{g} / \mathrm{ml}$.

Exposure to fungicides in amended water agar revealed that chlorothalonil at 0.01 $\mu \mathrm{g} / \mathrm{ml}$ and mancozeb at $2.5 \mu \mathrm{g} / \mathrm{ml}$ were sufficient to cause a significant decline in ascospore germination compared with the control. At concentrations of $0.07 \mu \mathrm{g} / \mathrm{ml}$ (chlorothalonil) and $7.0 \mu \mathrm{g} / \mathrm{ml}$ (mancozeb), ascospore germination was reduced to 0 , versus $98.9 \%$ germination for the control. Linear regression analysis of data obtained from the water agar experiments (Fig. 5) resulted in $\mathrm{EC}_{50}$ and $\mathrm{EC}_{90}$ estimates of 0.01 and $0.03 \mu \mathrm{g} / \mathrm{ml}$ for chlorothalonil, and 3.7 and $8.3 \mu \mathrm{g} / \mathrm{ml}$ for mancozeb.

Bioassay method for estimating chlorothalonil concentration. Growth inhibition of A. niger on filter paper disks on the surface of PDA-Aspergillus dishes was easily observed at $72 \mathrm{~h}$ and was compared with the disks on the control dishes, which showed $100 \%$ of the disks covered by fungal growth after $72 \mathrm{~h}$. The standard curve relating $\log _{10} \mu \mathrm{g} / \mathrm{ml}$ chlorothalonil to probit-transformed percent growth inhibition data for A. niger is shown in Figure 6 and is described by the regression equation $y=5.7+1.2(x)$ where $x=\log _{10} \mu \mathrm{g} / \mathrm{ml}$ chlorothalonil. The lowest concentration of chlorothalonil tested was $0.1 \mu \mathrm{g} / \mathrm{ml}$, which

Table 3. Percent growth inhibition of Aspergillus niger on filter paper disks saturated with dew water from banana leaves and corresponding estimates of chlorothalonil concentration $(\mu \mathrm{g} / \mathrm{ml})$ present in samples from Casmul Farm $24 \mathrm{~h}$ after an aerial spray application of chlorothalonil on two separate dates

\begin{tabular}{|c|c|c|c|c|c|c|c|c|c|c|}
\hline \multirow[b]{2}{*}{ Location } & \multicolumn{2}{|c|}{$\begin{array}{c}\text { Mean growth } \\
\text { inhibition }(\%)^{\mathrm{w}}\end{array}$} & \multicolumn{2}{|c|}{$\begin{array}{l}\text { Mean chlorothalonil } \\
\text { conc. }(\mu \mathrm{g} / \mathrm{ml})^{\mathrm{x}}\end{array}$} & \multicolumn{2}{|c|}{$\begin{array}{l}\text { Range of chlorothalonil } \\
\text { conc. }(\mu \mathrm{g} / \mathrm{ml})\end{array}$} & \multicolumn{2}{|c|}{ Total samples } & \multicolumn{2}{|c|}{$\begin{array}{c}\text { Samples with } \\
\text { chlorothalonil conc. } \\
\geq 0.1 \mu \mathrm{g} / \mathrm{ml} \\
\end{array}$} \\
\hline & Aug. 29 & Sept. 12 & Aug. 29 & Sept. 12 & Aug. 29 & Sept. 12 & Aug. 29 & Sept. 12 & Aug. 29 & Sept. 12 \\
\hline $\begin{array}{l}\text { Abaxial surface, } \\
\text { leaf C 3-4 days }\end{array}$ & $71.0 \mathrm{a}$ & $76.1 \mathrm{ab}$ & $1.5 \mathrm{a}$ & $1.2 \mathrm{ab}$ & 0.1 to 7.5 & 0.2 to 2.1 & 17 & 20 & 17 & 20 \\
\hline $\begin{array}{l}\text { Abaxial surface, } \\
\text { leaf C 8-10 days }\end{array}$ & $49.6 \mathrm{~b}$ & $72.5 \mathrm{~b}$ & $0.6 \mathrm{~b}$ & $1.0 \mathrm{~b}$ & 0.0 to 4.5 & 0.3 to 2.1 & 17 & 20 & 15 & 20 \\
\hline $\begin{array}{l}\text { Abaxial surface, } \\
\text { leaf } 1\end{array}$ & $44.4 \mathrm{~b}$ & $65.4 \mathrm{c}$ & $0.4 \mathrm{~b}$ & $0.7 \mathrm{c}$ & 0.0 to 2.1 & 0.1 to 1.4 & 17 & 15 & 16 & 15 \\
\hline $\begin{array}{l}\text { Abaxial surface, } \\
\text { leaf } 2\end{array}$ & $28.7 \mathrm{c}$ & 80.9 a & $0.1 \mathrm{~b}$ & $1.5 \mathrm{a}$ & 0.0 to 0.9 & 0.5 to 2.8 & 17 & 20 & 9 & 20 \\
\hline
\end{tabular}

\footnotetext{
${ }^{\mathrm{w}}$ Means followed by the same letter in each column are not significantly different according to Duncan's multiple range test $(P>0.05)$

${ }^{x}$ Estimated from regression equation in Figure 6.

y 3- to 4-day-old emerging leaf $\mathrm{C}$.

z 8- to 10-day-old emerging leaf $\mathrm{C}$.
} 
corresponded to a growth inhibition level of approximately $25 \%$ after $72 \mathrm{~h}$. This was considered the lower limit of detection for the assay.

Field studies. Estimates of chlorothalonil concentrations present in dew water in Banderas Farm ranged from $0.0 \mu \mathrm{g} / \mathrm{ml}$ to greater than $20 \mu \mathrm{g} / \mathrm{ml}$ (Table 2). One hundred percent of the samples taken from the adaxial surface of leaf 1 had a chlorothalonil concentration of at least $0.1 \mu \mathrm{g} / \mathrm{ml}$. Ninety-four percent of the samples from the abaxial surface of leaf 1 and the abaxial surface of leaf $\mathrm{C}$ had a concentration of at least $0.1 \mu \mathrm{g} / \mathrm{ml}$. Mean chlorothalonil concentrations in dew water samples from the adaxial surface of leaf 1 , the abaxial leaf surface of leaf 1 , and the abaxial surface of leaf $\mathrm{C}$ were $7.9,6.1$, and $1.4 \mu \mathrm{g} / \mathrm{ml}$, respectively.

Dew water samples taken on two separate dates from Casmul Farm (Table 3) showed trends that were similar to data from Banderas Farm. Eighty-eight to $100 \%$ of the samples taken from the abaxial surface of emerging leaves (leaf C) had chlorothalonil of at least $0.1 \mu \mathrm{g} / \mathrm{ml}$. For the abaxial surface of leaf 1,94 to $100 \%$ of the samples had chlorothalonil concentrations of at least $0.1 \mu \mathrm{g} / \mathrm{ml}$, and for the abaxial surface of leaf 2, 53 to $100 \%$ of the samples had at least $0.1 \mu \mathrm{g} / \mathrm{ml}$. Mean estimates of chlorothalonil concentration $(\mu \mathrm{g} / \mathrm{ml})$ across all samples, treatments, and dates ranged from 0.1 to $1.5 \mu \mathrm{g} / \mathrm{ml}$.

Analytical quantification of dew water from banana leaves in Casmul Farm showed that chlorothalonil was present in concentrations ranging from 1.85 to 20.9 $\mu \mathrm{g} / \mathrm{ml}$ (Table 4). Only five samples were taken due to high analytical costs, but the results confirmed the presence of chlorothalonil in dew water on both the adaxial and abaxial leaf surfaces from a farm sprayed by aircraft.

Spray droplet deposits of chlorothalonil recovered on water-sensitive paper placed on collection devices revealed that spray cards on the vertical dowel had the highest number of spray droplet deposits per $\mathrm{cm}^{2}$ (Table 5). The adaxial surface of horizontally inclined leaves received significantly $(P<0.05)$ higher droplet deposits than the abaxial surface. Extremely sparse deposits were recorded on the abaxial surface of leaves 4 and 5, which had angles with respect to vertical of $45^{\circ}$ and $90^{\circ}$, respectively.

Table 4. Results of analytical quantification of chlorothalonil concentrations $(\mu \mathrm{g} / \mathrm{ml})$ in dew water collected from banana leaves in the field ${ }^{\mathrm{z}}$

\begin{tabular}{lcc}
\hline Sample & Location & $\boldsymbol{\mu g} / \mathbf{m l}$ \\
\hline 1 & Adaxial surface, leaf 4 & 4.59 \\
2 & Adaxial surface, leaf 5 & 7.13 \\
3 & Adaxial surface, leaf 3 & 20.9 \\
4 & Abaxial surface, leaf C & 1.85 \\
5 & Abaxial surface, leaf C & 5.22 \\
\hline
\end{tabular}

${ }^{\mathrm{z}}$ Values are from single dew samples taken from each leaf with a micropipette.
Chlorothalonil spray droplet deposits (containing FD\&C no. 40 red dye) on white Kromekote spray cards placed in the banana foliage of the upper canopy confirmed that fungicide droplets were deposited on the abaxial leaf surfaces of vertical leaves during a commercial spray application (Table 6). Eighty-nine percent of the samples placed on the outside of leaf $\mathrm{C}$ received detectable deposits, resulting in a mean value of 17.9 spray droplet deposits per $\mathrm{cm}^{2}$. However, the abaxial surfaces of leaves 1,2 , and 3 received a very low number of spray droplet deposits, in contrast to the adaxial surfaces.

Chlorothalonil was recovered on filter paper samples placed on the foliage of immature banana plants during a commercial application (Table 7). The highest amount of chlorothalonil was detected on samples placed on the adaxial surface of leaves 1 and 2, and somewhat lower levels were found on the abaxial surface of leaf
C. The abaxial surface of leaves 1 and 2 received very small amounts of chlorothalonil. Eighty-three and $89 \%$ of these samples received no detectable chlorothalonil deposits.

\section{DISCUSSION}

A standardized bioassay that measured the early ( 0 to $72 \mathrm{~h}$ ) growth inhibition in vitro of $A$. niger by chlorothalonil was found to be a useful method in estimating chlorothalonil concentrations in dew water on banana foliage. The bioassay was an efficient and inexpensive technique for processing a large number of dew water samples from the field and was utilized to address questions relating to chlorothalonil distribution on banana foliage following aerial spray applications.

Field data obtained from the A. niger bioassay (Tables 2 and 3) indicated that chlorothalonil is present in sufficient concentration in dew water on the adaxial and

Table 5. Recovery of spray droplets per $\mathrm{cm}^{2}$ on collection devices placed within a banana plantation during an aerial application of chlorothalonil

\begin{tabular}{cccc}
\hline Sample site $^{\mathbf{x}}$ & Angle $^{\mathbf{y}}$ & Experiment 1 $^{\mathbf{z}}$ & Experiment 2 $^{\circ}$ \\
\hline $\mathrm{C}$ & $0^{\circ}$ & $111.5 \mathrm{a}$ & $59.8 \mathrm{a}$ \\
1 & $0^{\circ}$ & $16.5 \mathrm{~d}$ & $8.2 \mathrm{c}$ \\
$2 \mathrm{U}$ & $5^{\circ}$ & $39.9 \mathrm{c}$ & $14.6 \mathrm{~b}$ \\
$2 \mathrm{~L}$ & $5^{\circ}$ & $5.1 \mathrm{e}$ & $1.2 \mathrm{c}$ \\
$3 \mathrm{U}$ & $30^{\circ}$ & $31.7 \mathrm{c}$ & $19.4 \mathrm{~b}$ \\
$3 \mathrm{~L}$ & $30^{\circ}$ & $18.1 \mathrm{~d}$ & $0.4 \mathrm{c}$ \\
$4 \mathrm{U}$ & $45^{\circ}$ & $67.1 \mathrm{~b}$ & $32.7 \mathrm{ab}$ \\
$4 \mathrm{~L}$ & $45^{\circ}$ & $1.0 \mathrm{e}$ & $0.2 \mathrm{c}$ \\
$5 \mathrm{U}$ & $90^{\circ}$ & $63.4 \mathrm{~b}$ & $49.2 \mathrm{a}$ \\
$5 \mathrm{~L}$ & $90^{\circ}$ & $0.0 \mathrm{e}$ & $0.0 \mathrm{c}$ \\
\hline
\end{tabular}

$\overline{\mathrm{x}} \mathrm{C}=$ leaf $\mathrm{C} ; 1=$ leaf $1 ; 2=$ leaf $2 ; 3=$ leaf $3 ; 4=$ leaf $4 ; 5=$ leaf $5 ; \mathrm{U}=$ upper surface; $\mathrm{L}=$ lower surface.

y Angle with respect to vertical.

${ }^{\mathrm{z}}$ Means followed by the same letter in each column are not significantly different according to Duncan's multiple range test $(P>0.05)$.

Table 6. Recovery of spray droplet deposits in the upper canopy of banana foliage during an aerial spray application of chlorothalonil in Banderas Farm

\begin{tabular}{lcc}
\hline Location in canopy & Mean droplet deposits/cm & Samples, no droplet deposits $(\%)$ \\
\hline Leaf C & $17.9 \mathrm{~b}^{\mathrm{z}}$ & 11 \\
Leaf 1, adaxial surface & $31.5 \mathrm{a}$ & 0 \\
Leaf 1, abaxial surface & $0.2 \mathrm{c}$ & 56 \\
Leaf 2, adaxial surface & $29.1 \mathrm{a}$ & 0 \\
Leaf 2, abaxial surface & $0.2 \mathrm{c}$ & 59 \\
Leaf 3, adaxial surface & $24.1 \mathrm{ab}$ & 0 \\
Leaf 3, abaxial surface & $0.1 \mathrm{c}$ & 89
\end{tabular}

${ }^{\mathrm{z}}$ Means followed by the same letter are not significantly different according to Duncan's multiple range test $(P>0.05)$.

Table 7. Recovery of chlorothalonil active ingredient on filter paper samples placed in the banana leaf canopy during an aerial application of chlorothalonil

\begin{tabular}{lcc}
\hline Location & $\begin{array}{c}\text { Mean chlorothalonil } \\
\left(\boldsymbol{\mu g} \mathbf{a . i .} \mathbf{~ c m}^{-2}\right)\end{array}$ & $\begin{array}{c}\text { Samples with detectable } \\
\text { chlorothalonil }(\boldsymbol{\%})\end{array}$ \\
\hline Leaf C & $1.21 \mathrm{~b}^{\mathrm{z}}$ & 100 \\
Leaf 1, adaxial surface & $4.00 \mathrm{a}$ & 100 \\
Leaf 2, adaxial surface & $3.75 \mathrm{a}$ & 100 \\
Leaf 1, abaxial surface & $0.06 \mathrm{c}$ & 17 \\
Leaf 2, abaxial surface & $0.01 \mathrm{c}$ & 11 \\
\hline
\end{tabular}

${ }^{\mathrm{z}}$ Means followed by the same letter are not statistically significant according to Duncan's multiple range test $(P>0.05)$. 
abaxial leaf surfaces to prevent $M$. fijiensis ascospore germination and, consequently, black Sigatoka infection. Mean estimates of chlorothalonil concentration using the bioassay method ranged from 0.1 to 7.9 $\mu \mathrm{g} / \mathrm{ml}$, which exceed the $\mathrm{EC}_{90}$ value $(0.06$ $\mu \mathrm{g} / \mathrm{ml}$ ) of chlorothalonil for inhibition of M. fijiensis ascospore germination. Dew water samples with chlorothalonil concentrations greater than $0.9 \mu \mathrm{g} / \mathrm{ml}$ apparently contained particulate chlorothalonil, since $0.9 \mu \mathrm{g} / \mathrm{ml}$ is the maximum solubility of chlorothalonil in water $\left(25^{\circ} \mathrm{C}\right)$. Chlorothalonil concentrations detected in analytical procedures (Table 4) were of the same magnitude as those estimated by the $A$. niger bioassay and confirmed the presence of chlorothalonil in dew water on both leaf surfaces.

The finding that small fungicide concentrations present in dew water are capable of inhibiting spore germination is similar to the scenario described by Courshee (4) for copper fungicides and late blight control. Redistribution of fungicide in the surface water present on leaves is most likely the key factor in explaining the disease control obtained in the field with protectant fungicides, since it is plausible that free water on the leaf surface present as dew, or as rain and irrigation water, acts as the medium for fungicide uptake into the fungal cell $(4,15)$. In the case of black Sigatoka control, it is probable that fungicide redistribution is most critical on the abaxial leaf surface, which is thought to be the primary infection site (10). The low concentrations of mancozeb and chlorothalonil needed to suppress disease may compensate to some degree for overall low deposition efficiency of these fungicides on the banana foliage.

The studies that determined the recovery of spray droplet deposits and chlorothalonil on banana foliage revealed that, with the exception of the vertical leaf $\mathrm{C}$, the adaxial surface of horizontally inclined leaves received more spray droplet deposits than the abaxial surface (Tables 5 to 7). Conclusions were similar in studies employing three different experimental methodologies; fungicide active ingredient recovery, red tracer dye recovery on white paper, and water-sensitive paper placed on collection devices simulating the canopy architecture of a banana plant. Low relative spray deposits on the crop abaxial leaf surface also were reported by Uk and Courshee (14) and Kirk et al. (7) in their analysis of spray deposits penetrating into the cotton canopy. This study demonstrated that during an aerial spray application in a banana plantation, only the vertical leaves, or leaves that are nearly vertical, receive numerous deposits on the abaxial leaf surface. The most efficient fungicide deposition on the abaxial leaf surface of banana plants occurred on leaf $\mathrm{C}$, which is rolled up in a vertical cylinder during its emergence. This finding leads to the conclusion that most of the fungicide active ingredient detected in dew water from the abaxial surface of an individual leaf originates from an aerial application timed when that leaf was emerging.

Washington (15) recommended calibrating aerial sprays in banana to deliver spray droplets with a volume median diameter (vmd) of 300 to $400 \mu \mathrm{m}$ instead of the traditional finer droplet spectrum (vmd $=200$ to $300 \mu \mathrm{m}$ ) based on research demonstrating inhibition of $M$. fijiensis spore germination on the leaf surface containing low densities of large droplet deposits. However, Gohlich (6) and Kirk et al. (7) showed that small spray droplets are deposited more efficiently than large droplets on the abaxial surface of cotton leaves. Definitive recommendations on the proper spray application calibration of aerial sprays in banana must be reassessed since Washington et al. (17) reported that the abaxial surface of banana leaves is the primary infection site of $M$. fijiensis. Since the emergence of a new leaf on a banana plant varies from 9 to 14 days (18), spray applications of protectant fungicides in banana need to be applied at the same or higher frequency in order to ensure significant fungicide deposits on the abaxial leaf surface of these newly emerging leaves. Additionally, spray application strategies or technologies that maximize the amount of protectant fungicide deposited on the abaxial leaf surface would most likely improve disease control and lower the rate of fungicide needed.

The fungicidal activity of chlorothalonil and mancozeb to $M$. fijiensis ascospores was demonstrated by the observation that a 4-h exposure to either fungicide prevented their germination. Chlorothalonil's irreversible toxicity toward $M$. fijiensis spores is compatible with the finding in yeast cells in vitro that chlorothalonil binds with sulfhydril groups of cellular proteins such as glyceraldehyde-3-phosphate dehydrogenase, leading to irreversible enzyme inactivation (9). Additionally, Tillman et al. (13) reported that a 4-h incubation of Saccharomyces pastorianus in chlorothalonilamended growth medium resulted in the loss of cell viability.

The sensitivity of $M$. fijiensis ascospores to chlorothalonil was at least 100-fold higher than mancozeb in the experiments measuring $\mathrm{EC}_{50}$ and $\mathrm{EC}_{90}$ values of both fungicides. The differences in sensitivity were noted both on amended water agar and on banana leaf disks immersed in fungicide suspensions. The estimated $\mathrm{EC}_{50}$ value of chlorothalonil in water that resides on the banana leaf surface was estimated to be $0.03 \mu \mathrm{g} / \mathrm{ml}$ compared with $3.2 \mu \mathrm{g} / \mathrm{ml}$ for mancozeb. $\mathrm{EC}_{50}$ values of chlorothalonil and mancozeb for inhibition of conidia germination of Colletotrichum coccodes in vitro was reported to be between 0.01 and $0.1 \mu \mathrm{g} / \mathrm{ml}$ for chlorothalonil and greater than $1 \mu \mathrm{g} / \mathrm{ml}$ for mancozeb (5). Similarly, Zitter et al. (19) reported that chlorothalo- nil concentrations between 0.01 and 1 $\mu \mathrm{g} / \mathrm{ml}$ significantly reduced conidial germination of Ulocladium cucurbitae in vitro. Low concentrations of chlorothalonil also have been reported (1) to inhibit spore germination of the peanut late leaf spot pathogen Cercosporidium personatum and radial growth of Cryphonectria cubensis (3). However, chlorothalonil and mancozeb concentrations required to suppress sporangia and zoospore germination of Phytophthora infestans were reported to be in the range of 1 to $10 \mu \mathrm{g} / \mathrm{ml}$ (2), and in vivo, zoospores and sporangia were affected about equally by both fungicides. This indicates that relative sensitivity to chlorothalonil and mancozeb may vary considerably among pathogens.

\section{ACKNOWLEDGMENTS}

We thank J. French, R. Moser, D. Ingram, and M. Grove for their support of this research.

\section{LITERATURE CITED}

1. Brenneman, T. B., and Murphy, A. P. 1991. Activity of tebuconazole on Cercosporidium personatum, a foliar pathogen of peanut. Plant Dis. 75:699-703.

2. Bruck, R. I., Fry, W. E., Apple, A. E., and Mundt, C. C. 1981. Effect of protectant fungicides on the development stages of Phytophthora infestans in potato foliage. Phytopathology 71:164-166.

3. Conradie, E., Swart, W. J., and Wingfield, M. J. 1992. Semiselective medium for isolation of Cryphonectria cubensis. Phytopathology 82:1440-1442.

4. Courshee, R. J. 1967. Application and use of foliar fungicides. Pages 240-284 in: Fungicides, An Advanced Treatise. Vol. 1. D. C Torgeson, ed. Academic Press, New York.

5. Dillard, H. R. 1988. Influence of temperature, $\mathrm{pH}$, osmotic potential, and fungicide sensitivity on germination of conidia and growth from sclerotia of Colletotrichum coccodes in vitro. Phytopathology 78:1357-1361.

6. Gohlich, H. 1985. Deposition and penetration of sprays. Pages 173-181 in: BCPC Monogr. No. 28, Symp. Applic. Biol.

7. Kirk, I. W., Bouse, L. F., Carlton, J. B., Franz, E., Latheef, M. A., Wright, J. E., and Wolfenberger, D. A. 1994. Within-canopy spray distribution from fixed-wing aircraft. Trans. ASAE 37:745-752.

8. Lhomme, J. P., and Jimenez, F. 1992. Estimating dew duration on banana and plantain leaves from standard meteorological observations. Agric. For. Meteorol. 62:263-274.

9. Long, J. W., and Siegel, M. R. 1975. Mechanism of action and fate of the fungicide chlorothalonil (2,4,5,6-tetrachloroisophtalonitrile) in biological systems. II. Chem.-Biol. Interact. 10:383-394.

10. Stover, R. H. 1972. Banana, Plantain, and Abaca Diseases. Commonw. Mycol. Inst. Kew, Surrey, Eng.

11. Stover, R. H. 1980. Sigatoka leaf spots of bananas and plantains. Plant Dis. 64:750-756.

12. Stover, R. H., and Simmonds, N. W. 1987 Bananas. John Wiley \& Sons, New York.

13. Tillman, R. W., Siegel, M. R., and Long, J. W. 1973. Mechanism of action and fate of the fungicide chlorothalonil (2,4,5,6-Tetrachlorisophtalonitrile) in biological systems. I. Reactions with cells and subcellular components of Saccharomyces pastorianus. Pestic. Biochem. Physiol. 3:160-167.

14. Uk, S., and Courshee, R. J. 1982. Distribution and likely effectiveness of spray deposits within a cotton canopy from fine ULV sprays 
applied by aircraft. Pestic. Sci. 13:529-536.

15. Washington, J. R. 1997. Relationship between the spray droplet density of two protectant fungicides and the germination of Mycosphaerella fijiensis ascospores on banana leaf surfaces. Pestic. Sci. 50:233-239.

16. Washington, J. R., and Cruz, J. 1996. Distribution of Mycosphaerella fijiensis ascospores and conidia trapped on the leaf surface in relation to the location in the banana canopy. (Abstr.) APS/MSA Joint Annu. Meet., July 27-31, Indianapolis, IN. p. 85.

17. Washington, J. R., Cruz, J., Lopez, F., and Fajardo, M. 1998. Infection studies of Mycosphaerella fijiensis on banana and the control of black Sigatoka with chlorothalonil. Plant
Dis. 82:1185-1190.

18. Wielemaker, F. 1989. Notes on some practical aspects of black Sigatoka control. Proc. Annu. Meet. ACORBAT, San Jose, Costa Rica.

19. Zitter, T. A., and Hsu, L. W. 1992. Influence of temperature and fungicide on germination, growth, and virulence of Ulocladium cucurbitae on cucumber. Phytopathology 82:358-362. 